\title{
MARKET ORIENTATION, COMPETITIVE ADVANTAGE AND BUSINESS PERFORMANCE: EXPLORING THE INDIRECT EFFECTS
}

Anita TALAJA, Dario MIOČEVIĆ, Nikša ALFIREVIĆ

Faculty of Economics, Split

Jurica PAVIČIĆ

Faculty of Economics and Business, Zagreb

UDK: $339.137(497.5)$

334.012.61(497.5):005.343

Izvorni znanstveni rad

Primlieno: 16. 2. 2017

In this paper, we address insufficiently explored indirect relationships between market orientation (MO), organizational strategic resources and business outcomes. Previous studies have identified $M O$ as a key strategic asset that contributes to competitive advantage and ultimately to business performance. However, the extant research is at best partial in addressing the contingencies that might uphold these relationships. The goal of this study is to extend the existing knowledge by showing that $M O$ complements with other strategic management processes that are relevant for business success. To address the research question, a conceptual model with three hypotheses was developed. Data was obtained with a survey questionnaire on a sample of 265 medium and large-sized firms from Croatia. The findings indicate that $\mathrm{MO}$ influences competitive advantage stronger at higher levels of VRIN resources. Also, findings suggest that competitive advantage mediates the relationship between $\mathrm{MO}$ and business performance. In the end, the theoretical and managerial implications are presented along with future research directions in light of the limitations of this study.

Keywords: resource-based view, market orientation, competitive advantage, business performance 
Throughout the last two and a half decades, research on market orientation $(\mathrm{MO})$ has gained abundant popularity in academia (e.g., Ellis, 2006; Jaworski \& Kohli, 1993; Narver \& Slater, 1990). Dominant literature has viewed MO as a key leverage for achieving competitive advantage, through understanding the needs of customers, competitive structure and the general business environment. While the majority of marketing literature considered $\mathrm{MO}$ as the backbone of successful marketing program implementation, Foley and Fahy (2009) have proposed a perspective that positioned MO in the domain of strategic intangible assets. In this line of reasoning, a substantial body of literature framed $\mathrm{MO}$ as a key intangible asset crucial for achieving sustainable competitive advantage (e.g., Lonial \& Carter, 2015; Miocevic \& Crnjak-Karanovic, 2011; Murray et al., 2011; Ngo \& O'Cass, 2012; O'Cass et al., 2015).

A recent meta-analytical review suggests that MO was dominantly seen as an expression of marketing concept within organizations and a key platform for the successful management of lower-level marketing activities (Kirca, Jayachandran, \& Bearden, 2005) without the ambition to reveal MO's key position in developing a firm's strategic posture. The first attempt to bring together the 'compatible' views of marketing and strategic management literature can be attributed to Hunt and Morgan (1995), who developed the resource advantage ( $R-A)$ theory. Their point of departure was based on the fact that the (neo)classical economic theories were not able to explain market innovation, or the diversity of firms and their strategies. In a further attempt, Srivastava, Fahey, and Christensen (2001) proposed that the process by which the market-based assets and capabilities are transformed into customer value/performance should be a research priority.

Recently, a number of studies have confirmed the strategic importance of MO. Theory sees resources and competencies as different ways of painting the canvas of strategy, which is being constantly re-arranged, as to fit the needs of customers and other stakeholders. In this stream of research, studies have shown that $\mathrm{MO}$ works in concert with other tangible and intangible resources in explaining a firm's superior competitive position and performance (Cacciolatti \& Lee, 2016; O'Cass et al., 2015; Zhang \& Zhu, 2016), thus confirming its strategic role.

By building on the arguments from the resource-based view (RBV) of the firm (Wernfelt, 1984; Barney, 1986), this study aims to contribute by extending the knowledge of $\mathrm{MO}$ literature in three ways. First, we will demonstrate that the relationship between $\mathrm{MO}$ and competitive advantage is mod- 
DRUŠ. ISTRAŽ. ZAGREB GOD. 26 (2017), BR. 4 STR. 583-604

TALAJA, A., MIOČEVIĆ D., ALFIREVIĆ, N. PAVIČIĆ, J.: MARKET' ORIENTATION.. erated by the valuable, rare, inimitable and non-substitutable (VRIN) resource bundle that the firm possesses. Previous studies have partially investigated the interplay between $\mathrm{MO}$ and various organizational resources and a more comprehensive assessment of the firm's strategic resource needs to be integrated in this inquiry. By this means our study will contribute to the strategic marketing literature by outlining that the MO's ability to trigger competitive advantage is highly dependent on the firm's strategic resources. In other words, market-oriented behaviors need substantial resource support in order to transform a firm into a market leader. Secondly, the link between $\mathrm{MO}$ and business performance has been extensively researched in the literature (e.g., Ellis, 2006). However, very little is known how MO complements the firm's strategic management process. To this end, with our study we will show that MO's influence on business performance is highly mediated by the firm's ability to develop a competitive advantage. Thirdly, although most of the studies have been conducted in the context of developed, and some of them in emerging markets, little is said about MO's strategic role in the context of South-East and Central European transition market firms (i.e., Božić \& Rajh, 2008; Snoj, Milfelner, \& Gabrijan, 2007; Miocevic \& Crnjak-Karanovic, 2011; Pecotich, Crnjak-Karanović, \& Renko, 2007; Agić, Činjarević, Kurtović, \& Čičić, 2016). By focusing on the unique dataset of Croatian companies, our study will contribute to a higher generalizability of findings with regard to how MO and VRIN resources enhance a firm's competitive advantage and business performance.

The paper is therefore structured as follows. First, a conceptual framework along with literature review concerning the main inquiry is addressed. This is followed by the research hypotheses. The method section is then explained, along with the sampling procedures, measurement and operational definitions and the analytical tools that will be used. The method section is followed by the results with respect to measurement properties and the structural model. The discussion of findings is considered in terms of theoretical and managerial implications. Towards the end, limitations and suggestions for further research are presented.

\section{CONCEPTUAL FRAMEWORK}

Our study's conceptual model is framed around the arguments from the RBV of the firm. During the last two decades researchers started appreciating intangible assets as a means of achieving sustainable competitive advantage. The seminal work of Teece, Pisano, and Shuen (1997) has positioned capabili- 
DRUŠ. ISTRAŽ. ZAGREB GOD. 26 (2017), BR. 4, STR. 583-604

TALAJA, A., MIOČEVIĆ D., ALFIREVIĆ, N. PAVIČı́́, J. MARKET ORIENTATION.. ties and competencies as an inevitable source of the firm's competitiveness because of difficulties in acquiring and imitating them. Strategic competencies have been defined in terms of activating and using strategic resources to address the environmental challenges (Amit \& Shoemaker, 1993). They coordinate the usage of strategic resources (Grant, 1991) and help organizations adapt to environmental dynamics, as well as assist in discovering/implementing resource-based strategies (Collis, 1994).

Strategic marketing literature has widely embraced RBV for explaining market-related organizational behavior. Day (1994) recognized capabilities and competencies as the key organizational assets that enable firms to better connect with customers. In their influential study, Kohli and Jaworski (1990) examined the state of knowledge related to the implementation of the marketing concept and referred to the managerial framework, used for its implementation, in terms of 'market orientation' (MO), based on the organizational flow of market-related information. Desphande, Farley and Webster (1993) offered another conceptualization of MO that focuses on organizational culture. According to this perspective, $\mathrm{MO}$ distinguishes organizations with different levels of 'customer orientation'. Firms with higher levels of customer orientation prioritize customers' interests and this results in long-term profitability. Narver and Slater (1990) enriched the MO conceptualization by adding the 'competitor orientation' dimension that is related to understanding competitive market offerings. However, because of insufficient strategic perspective, the mainstream MO literature suffered a lot of criticism (Connor, 2007). Though Ketchen, Hult, and Slater (2007) emphasized the usefulness of RBV lens to investigate the organization-wide influence of MO. They also indicated that future research should analyze the strategic resources - strategic action - competitive advantage - performance linkages. Most recently researchers have started to appreciate the strategic role of $\mathrm{MO}$ in organizations. A plethora of strategic marketing studies showed that MO is an inevitable asset in building a firm's ability to sustain competitive advantage long-term, thus indicating its strategic importance (Foley \& Fahy, 2009; Morgan, Slotegraaf, \& Vorhies, 2009; Morgan, Vorhies, \& Mason, 2009; O'Cass \& Sok, 2014). As a result, the significant stream of research has labeled market-oriented behaviors as a key strategic asset that leads to competitive advantage. Studies in this area have shown that market-oriented behaviors of intelligence generation, dissemination and responsiveness enable firms to create value-added offerings for customers that result in a superior competitive position in the marketplace (Cacciolatti \& Lee, 2016; Murray et al., 2011; Ngo \& O'Cass, 2012; Rakthin, Calantone, \& Wang, 2016). 
DRUŠ. ISTRAŽ. ZAGREB GOD. 26 (2017), BR. 4 STR. 583-604

TALAJA, A., MIOČEVIĆ, D., ALFIREVIĆ, N. PAVIČIĆ, J.: MARKET' ORIENTATION..
The importance of resources for market-based strategy has been widely discussed in the strategic management literature. Barney's (1986) study, concentrating on the market availability of resources required for implementation of strategies, is considered as a cornerstone of a new approach to explaining competitive advantage of the firm. Through the RBV lens, Barney (1991) and Grant (1991) suggested that resources which are valuable, rare, imperfectly imitable and non-substitutable can lead to sustainable competitive advantage. By drawing on these ideas, we posit that the firm's MO will enhance competitive advantage more strongly when the deployed resources satisfy the VRIN criteria.

The issue of identifying the presence of competitive advantage, as a result of adequate patterns of resource/competence utilization and complementarity, has been widely debated. In their review, Ketchen et al. (2007) warn that MO should be assessed in a greater nomological network of strategic management processes. The capability-based view places $\mathrm{MO}$ as a key strategic asset that is indispensable in enhancing the firm's business performance (Foley \& Fahy, 2009). However, in line with strategic management literature, the successful creation of competitive advantage is an inevitable step that explains the process of how the firm's MO increases business performance.

Our conceptual framework envisioned through RBV theory suggests that $\mathrm{MO}$ improves competitive advantage, which eventually increases the business performance of a firm. The MO orchestrates the organizational activities that shape the emergence of competitive advantage (due to the alignment of operational activities with market requirements), as well as business performance. The graphical depiction of our model is presented in Figure 1 and the discussion of research hypotheses follows.

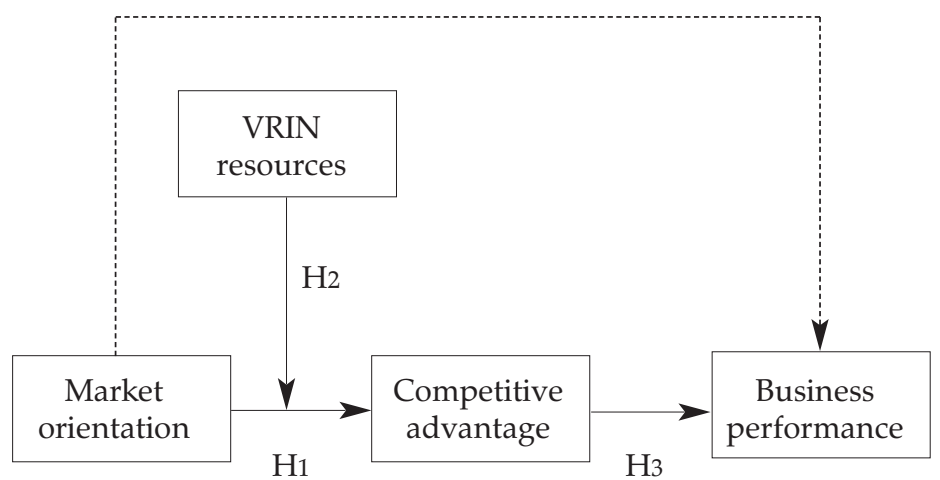




\section{RESEARCH HYPOTHESES}

\section{Market orientation and competitive advantage}

Kohli and Jaworski's (1990) and Narver and Slater's (1990) seminal works have been widely used to denote the importance of a firm's market-oriented behaviors in sustaining competitive advantage. $\mathrm{MO}$ is understood as a 'philosophy', serving as a foundation in explaining the strategic management process within the firm (Ketchen et al., 2007). This theoretical approach is especially relevant for the purpose of this paper, which brings together constructs from both the strategic marketing and strategic management fields. In their paper, Hult, Ketchen, and Slater (2005) tried to integrate cultural framework with the market-based information perspective. They hypothesized the existence of relationships between $\mathrm{MO}$ and organizational responsiveness, as well as between responsiveness and performance. In this context, $\mathrm{MO}$ is beheld as a strategic marketing asset (in line with the RBV view) and it is concluded that $\mathrm{MO}$ represents a significant antecedent of the firm's competitive position.

The MO-competitive advantage relationship is a significant part of strategic marketing research. More recently, researchers have extended the knowledge of MO's indispensable role in attaining sustainable competitive advantage in various areas (Kumar, Jones, Venkatesan, \& Leone, 2011; Lonial \& Carter, 2015; Miocevic \& Crnjak-Karanovic, 2011; Murray et al., 2011; Ngo \& O'Cass, 2012; O'Cass et al., 2015). Hence, we hypothesize the following:

H1: Market orientation has a positive and significant influence on a firm's competitive advantage.

\section{Moderating role of the VRIN resources on the relationship between market orientation and competitive advantage}

Hunt and Morgan (1995) argued that MO represents an "organizing framework", which can become "culturally embedded in an organization" (p. 11). It is discussed that MO can lead to sustainable competitive advantage, by supplementing the marketing concept itself and providing relevant information for strategy selection. In this process, the $\mathrm{MO}$ is expected to deliver the relevant information about customers and competitors and contribute to the selection of a strategy leading to competitive advantage. However, in this process, the firm needs substantial resource background to fulfill its strategic marketing intents manifested through $\mathrm{MO}$.

Day (1994) espoused that strategic market assets and capabilities have a key role in creating market-oriented organizations. The marketing capability framework follows the RBV prescription of $\mathrm{MO}$ being a strategic competency that needs a 
DRUŠ. ISTRAŽ. ZAGREB GOD. 26 (2017), BR. 4 STR. 583-604

TALAJA, A., MIOČEVIĆ D., ALFIREVIĆ, N. PAVIČIĆ, J.: MARKET' ORIENTATION.. resource platform in order for the firm to reach market success (Foley \& Fahy, 2009). Recent literature offers unequivocal empirical evidence as to how MO works in concert with other tangible and intangible resources in explaining the firm's competitive edge. In their study, Gaur, Vasudevan, and Gaur (2011) revealed that the MO's link with superior performance is orchestrated by the firm's resources. O'Cass, Ngo, and Siathiri (2015) have found that marketing resources have a significant role in enhancing the relationship between $\mathrm{MO}$ and performance outcomes. Zhang and Zhu (2016) found that MO improves a firm's strategic position measured through new product performance. Preceding studies in the field show indirect effects of how $\mathrm{MO}$ improves, through the enabling role of strategic resources, different aspects of competitive advantage. Based on this discussion we hypothesize the following:

H2: The relationship between market orientation and a company's competitive advantage is moderated by valuable, rare, inimitable and non-substitutable resources.

\section{Mediating role of competitive advantage in market orientation-business performance relationship}

In strategic management literature, there is an everlasting debate about how performance outcomes should be identified and specified (Day \& Wensley, 1988) and whether the indicators of business performance and competitive advantage should be used interchangeably (Hao Ma, 2000). Newbert's (2007) study showed that researchers usually do not seem to be concerned with these issues, with $76 \%$ of empirical studies investigating resource/competence - performance interface implying equal status of performance and competitive advantage constructs (Newbert, 2007). In his influential article, Powell (2001) states that sustained superior performance is a dependent variable in strategy research, while the competitive advantage construct should be used only if it provides an adequate understanding of how performance is achieved. Obviously, financial measures cannot be used to indicate the existence of a 'realistic' market advantage. Recent studies argue that competitive advantage is an antecedent to superior performance, suggesting that performance and competitive advantage should be empirically tested as related, but separate constructs (Navarro, Losada, Ruzo, \& Diez, 2010; Spanos \& Lioukas, 2001). This is in line with the view that MO has an intrinsic value for a firm's strategic management processes by enhancing business performance through the creation of competitive advantage (Hult et al., 2005; Ketchen et al., 2007). Therefore, we propose the following hypothesis:

H3: The relationship between MO and business performance is mediated by competitive advantage. 
For the purpose of this study a survey was conducted. Primary data was collected from medium and large-sized Croatian firms. The sampling frame was drawn from the Croatian Chamber of Economy and resulted in a population of 1017 firms. The sampling frame comprised active firms from a wide range of industries defined by the Croatian National Industrial Classification System. According to the Croatian Accounting Law, medium and large-sized firms have: (1) more than 250 employees, (2) yearly turnover that exceeds 260 million kuna (Croatia's national currency) and, (3) assets that exceed 130 million kuna.

A self-administered questionnaire was developed and questionnaire items were translated into Croatian. For the purpose of data collection, online and mail surveys were sent to the address of the chief executive officer (CEO) simultaneously in order to increase the response rate. In the end, a total of 265 usable surveys were returned resulting in a response rate of $26.06 \%$, which is deemed acceptable for this type of research (Protogerou, Caloghirou, \& Lioukas, 2008). Out of 265 usable questionnaires, $144(54.3 \%)$ were collected through a mail survey, while 121 (45.7\%) questionnaires were collected via an online survey. To secure the validity of the data collection process, t-tests were performed to determine if the different modes of response were an issue. The results revealed no statistically significant differences in terms of these two types of responses to the survey $(p>0.05)$. Eventually there were $108(40.8 \%)$ large, and $157(59.2 \%)$ medium-sized firms in the sample, of which $46(17.4 \%)$ firms are in foreign and $219(82.6 \%)$ in domestic ownership.

\section{Measurement operationalization}

MO was measured by the adopted MARKOR scale, with items related to intelligence generation, intelligence dissemination and responsiveness (Jaworski \& Kohli, 1993; Kohli, Jaworski, \& Kumar, 1993).

VRIN resources were operationalized according to the theoretical recommendations provided by Makadok (2001) and Newbert $(2007,2008)$. Barney's (1995) original classification of resources was adopted and complemented with Newbert's (2008) category of intellectual resources. Thus, value, rareness, inimitability and non-substitutability (VRIN characteristics) of physical (PH), human (HU), organizational (OR), intellectual (IN) and financial (FI) resources were assessed. PH/HU/OR/IN/FI resources were measured by multiple items, describing each 
DRUŠ. ISTRAŽ. ZAGREB GOD. 26 (2017), BR. 4 STR. 583-604

TALAJA, A., MIOČEVIĆ D., ALFIREVIĆ, N., PAVIČIĆ, J.: MARKET' ORIENTATION.. of the VRIN characteristics. The value aspect was measured by asking respondents "to what extent do the $\mathrm{PH} / \mathrm{HU} / \mathrm{OR} / \mathrm{IN} / \mathrm{FI}$ resources enable your firm to neutralize threats originating from the business environment?" The rareness aspect was measured by asking respondents "to what extent are the $\mathrm{PH} /$ HU/OR/IN/FI resources unique for your firm?" The inimitability aspect was measured by asking respondents "to what extent can competitors replicate $\mathrm{PH} / \mathrm{HU} / \mathrm{OR} / \mathrm{IN} / \mathrm{FI}$ resources of your firm?" The non-substitutability aspect was measured by asking respondents "to what extent is it possible to achieve the same effects of $\mathrm{PH} / \mathrm{HU} / \mathrm{OR} / \mathrm{IN} / \mathrm{FI}$ resources in a different way?" The five-point measurement scale was used with anchors $1=$ not at all and $5=$ entirely. For the convenience of the analysis, all of the VRIN aspects were mean-centered and consolidated into the composite measures for each type of resources.

Competitive advantage was measured by asking respondents' to assess the firm's success in comparison to major competitors, along the following aspects (Peteraf \& Barney, 2003): a general advantage (or disadvantage) over competitors (CA1); sustainability of acquired advantage (CA2); the product/service quality and image (CA3); price of products/services (CA4); the production cost of product or cost of service delivery (CA5) and customer satisfaction with product/service (CA6).

Given that the perceptual measures of performance correlate with objective measures (Powell, 2001), business performance was measured through managers' perceptions of sales (PERF1), sales growth (PERF2), profitability (PERF3), market share (PERF4), increase in market share (PERF5) and sustainability of achieved performance levels (PERF6). Competitive advantage and business performance were assessed on a five-point Likert-type scales ranging from $1=$ much worse than competitors to $5=$ much better than competitors. Measurement scales and their responding items can be found in Appendix 1 .

\section{Common method bias}

Because all data were self-reported and collected with the same instrument in cross-sectional research design, common method variance (CMV) could have become a source of systematic measurement error and further biased the estimates of the relationships among theoretical constructs (Podsakoff, Mckenzie, Lee, \& Podsakoff, 2003). To determine whether common method bias was an issue, two specific post hoc statistical remedies were employed. First, Harman's one-factor test was conducted. After all the 31 variables were entered into factor analysis, the presence of 11 distinct factors with eigenvalue greater than one was revealed. These 11 factors together ac- 
DRUŠ. ISTRAŽ. ZAGREB GOD. 26 (2017), BR. 4, STR. $583-604$

TALAJA, A., MIOČEVIĆ D., ALFIREVIĆ, N PAVIČIĆ, J.:

MARKET ORIENTATION. counted for $64.85 \%$ of the total variance, while the first (largest) factor did not account for the majority of the variance $(10.54 \%)$. Second, we obtained data on the firm's sales revenues and profitability indicators for the sample firms. The correlation analysis showed a significant relationship between subjective (survey), and objective sales revenues and profitability indicators $(p<0.05)$. Thus, we conclude that no common factor underlies our study's inquiry.

\section{Analytical strategy}

Because of the moderate sample size and sufficiently developed theoretical background, we used a partial least squares (PLS) analysis. PLS is a general technique for estimating path models involving latent constructs that are indirectly observed by multiple indicators. It was developed by Wold (1980) in order to avoid the necessity of large sample sizes. PLS enables the simultaneous analysis of the outer (measurement) and inner (path) models. Reinartz, Haenlain, and Henseler (2009) suggested that PLS be used to estimate model prediction when the sample size is small (but larger than 100). More recently, PLS modeling has been used as an analytical strategy in strategic marketing studies (e.g., Ngo \& O'Cass, 2012; O'Cass et al., 2015; Rakthin et al., 2016).

\section{FINDINGS}

\section{Measurement model}

In order to test the properties of the measurement model, the estimates for the relationships between the reflective latent variables and their indicators, outer model loadings were examined. The loadings of all reflective indicators were examined to assess the indicator reliability. Indicator reliability specifies which part of an indicator's variance can be explained by the underlying latent variable (Götz, Liehr-Gobbers, \& Krafft, 2010). From Table 1, it is evident that outer model loadings are above critical level of 0.6 except for the following items: MO6, CA4, VRIN4 and VRIN5, which had lower loadings on their respective constructs and were excluded from further analysis. Eventually, to further check the unidimensionality of our measures we explored the possible cross-loadings. We found no substantial cross-loadings among the constructs of interest.

Construct reliability indicates whether all the construct's indicators jointly measure the construct adequately (Götz et al., 2010). According to Bagozzi and Yi (1988), composite reliabilities (CR) larger than 0.6 are considered as acceptable. The findings from Table 1 indicate that CR of all respective con- 
- TABLE 1

Measurement

model properties structs is above the cut-off value, suggesting that measures demonstrate high levels of internal consistency.

\begin{tabular}{|c|c|c|c|c|}
\hline Constructs & $\begin{array}{r}\text { Factor } \\
\text { loading }\end{array}$ & $\begin{array}{r}\text { Cronbach } \\
\alpha\end{array}$ & CR & AVE \\
\hline $\begin{array}{l}\text { MO - Intelligence generation } \\
\text { MO1 } \\
\text { MO2 } \\
\text { MO3 } \\
\text { MO4 } \\
\text { MO5 }\end{array}$ & $\begin{array}{l}0.74 \\
0.77 \\
0.86 \\
0.84 \\
0.71\end{array}$ & 0.84 & 0.89 & 0.62 \\
\hline $\begin{array}{l}\text { MO - Intelligence dissemination } \\
\text { MO6 } \\
\text { MO7 } \\
\text { MO8 } \\
\text { MO9 }\end{array}$ & $\begin{array}{l}0.57 \\
0.78 \\
0.81 \\
0.69\end{array}$ & 0.71 & 0.81 & 0.52 \\
\hline $\begin{array}{l}\text { MO - Responsiveness } \\
\text { MO10 } \\
\text { MO11 } \\
\text { MO12 } \\
\text { MO13 } \\
\text { MO14 }\end{array}$ & $\begin{array}{l}0.75 \\
0.81 \\
0.74 \\
0.80 \\
0.81\end{array}$ & 0.84 & 0.89 & 0.62 \\
\hline $\begin{array}{l}\text { Competitive advantage } \\
\text { CA1 } \\
\text { CA2 } \\
\text { CA3 } \\
\text { CA4 } \\
\text { CA5 } \\
\text { CA6 }\end{array}$ & $\begin{array}{l}0.77 \\
0.82 \\
0.73 \\
0.51 \\
0.64 \\
0.67\end{array}$ & 0.78 & 0.85 & 0.55 \\
\hline $\begin{array}{l}\text { VRIN resources } \\
\text { VRIN1 } \\
\text { VRIN2 } \\
\text { VRIN3 } \\
\text { VRIN4 } \\
\text { VRIN5 }\end{array}$ & $\begin{array}{l}0.70 \\
0.63 \\
0.65 \\
0.48 \\
0.52\end{array}$ & 0.68 & 0.79 & 0.53 \\
\hline $\begin{array}{l}\text { Business performance } \\
\text { Perf1 } \\
\text { Perf2 } \\
\text { Perf3 } \\
\text { Perf4 } \\
\text { Perf5 } \\
\text { Perf6 }\end{array}$ & $\begin{array}{l}0.80 \\
0.79 \\
0.78 \\
0.76 \\
0.83 \\
0.72\end{array}$ & 0.87 & 0.90 & 0.62 \\
\hline
\end{tabular}

The other important construct reliability measure is Cronbach's Alpha, which quantifies how well a set of indicators measures the unidimensional latent construct (Götz et al., 2010). Cronbach $\alpha$ values larger than 0.6 are considered acceptable (Hair, Black, Babin, \& Anderson, 2010). From Table 1 it is transparent that all Cronbach's $\alpha$ indicators are above the cut-off value. 
DRUŠ. ISTRAŽ. ZAGREB GOD. 26 (2017), BR. 4, STR. 583-604

TALAJA, A., MIOČEVIĆ, D., ALFIREVIĆ, N. PAVIČIĆ, J. MARKET ORIENTATION..

(1) TABLE 2

Intercorrelation matrix and discriminant validity test
Convergent validity refers to the extent to which blocks of items strongly agree or converge in their representation of the underlying constructs they were supposed to measure. The convergent validity has been assessed via average variance extracted (AVE) value. In this model, the AVE values of all respective constructs are above the cut-off rate of 0.50 . Thus we conclude that our measures exhibit a satisfactory level of convergent validity.

To inspect the discriminant validity we followed the procedure introduced by Fornell and Larcker (1981) (see Table 2). According to the Fornell-Larcker criterion, the square root of the AVE of each latent construct should be higher than the construct's highest correlation with any other latent construct. Table 2 displays the results in regard to the Fornell-Larcker criterion. The square root of AVE is on the diagonal and the correlations between the constructs are in the lower left triangle of Table 2 .

\begin{tabular}{llrrrrrr}
\hline & 1 & 2 & 3 & 4 & 5 & 6 \\
\hline 1 & Competitive advantage & 0.70 & & & & & \\
2 & Intelligence generation & 0.45 & 0.72 & & & & \\
3 & Intelligence dissemination & 0.53 & 0.68 & 0.79 & & & \\
4 & Business performance & 0.69 & 0.40 & 0.43 & 0.78 & & \\
5 & Responsiveness & 0.56 & 0.64 & 0.69 & 0.45 & 0.78 & \\
6 & VRIN resources & 0.21 & 0.06 & 0.13 & 0.08 & 0.18 & 0.46 \\
\hline
\end{tabular}

The square roots of the AVEs of all constructs are higher than the correlations of these constructs with other latent variables. Therefore, we conclude that the discriminant validity of measures has been established.

To measure the PLS path model fit, literature suggests using global goodness of fit (GoF) measure (Wetzels, Odekerken-Schröder, \& van Oppen, 2009). Global GoF can be calculated as the geometric mean of the average communality (AVE) and average $R^{2}$ for endogenous constructs in the model (competitive advantage and business performance). According to the obtained results, global GoF of our PLS path model is 0.497, which exceeds the cut-off value of 0.36 for large effect size of $R^{2}$. Therefore, we conclude that our PLS path model is satisfactory according to the established standards.

\section{Structural model}

After assessing the dimensionality, reliability and validity of the used measures, the structural model was estimated. In this regard, the path coefficients and significance levels, as well as endogenous variables' determination coefficient $\left(R^{2}\right)$ were evaluated (Götz et al., 2010). Since PLS does not assume 
DRUŠ. ISTRAŽ. ZAGREB GOD. 26 (2017), BR. 4 STR. 583-604

TALAJA, A., MIOČEVIĆ D., ALFIREVIĆ, N. PAVIČIĆ, J.: MARKET' ORIENTATION

? FIGURE 2

Moderating effect of VRIN resources in the MO-competitive advantage relationship that data is normally distributed, parametric significance tests used in regression analyses cannot be applied to test if outer model loadings are significant. Instead, to estimate the statistical significance of the PLS path model coefficients, PLS relies on a nonparametric bootstrap procedure (Chin, 2010).

$\mathrm{H} 1$, which asserts that $\mathrm{MO}$ positively affects competitive advantage, was supported $(\beta=0.59, p<0.01)$. From the results, it can be seen that $\mathrm{MO}$ has a strong direct effect on CA and consequently explains $34.8 \%$ of the variance in the CA construct $\left(R^{2}=0.348\right)$. In order to test the moderating effect of VRIN resources in the relationship between MO and business performance $(\mathrm{H} 2)$, an interaction effects test was employed (Chin, Marcolin, \& Newsted, 2003). The interaction effects method is appropriate in the case when moderator construct has at least two indicators. The relationship between $\mathrm{MO}$ and competitive advantage (direct effect) was found to be positive and significant as posited in $\mathrm{H} 1$ ( $\beta=0.59, p<$ 0.01 ). After including the VRIN resources as moderator in the relationship between $\mathrm{MO}$ and competitive advantage, the model $R^{2}$ rose to $0.366\left(\Delta R^{2}=0.018 ; \Delta F\right.$-statistic $\left.=0.009\right)$ and the interaction term was found to be positive and significant $(\beta=0.13, p<0.01)$. To better present this finding, we plotted the moderating effects in Figure 2. Eventually we found substantial evidence to accept $\mathrm{H} 2$.

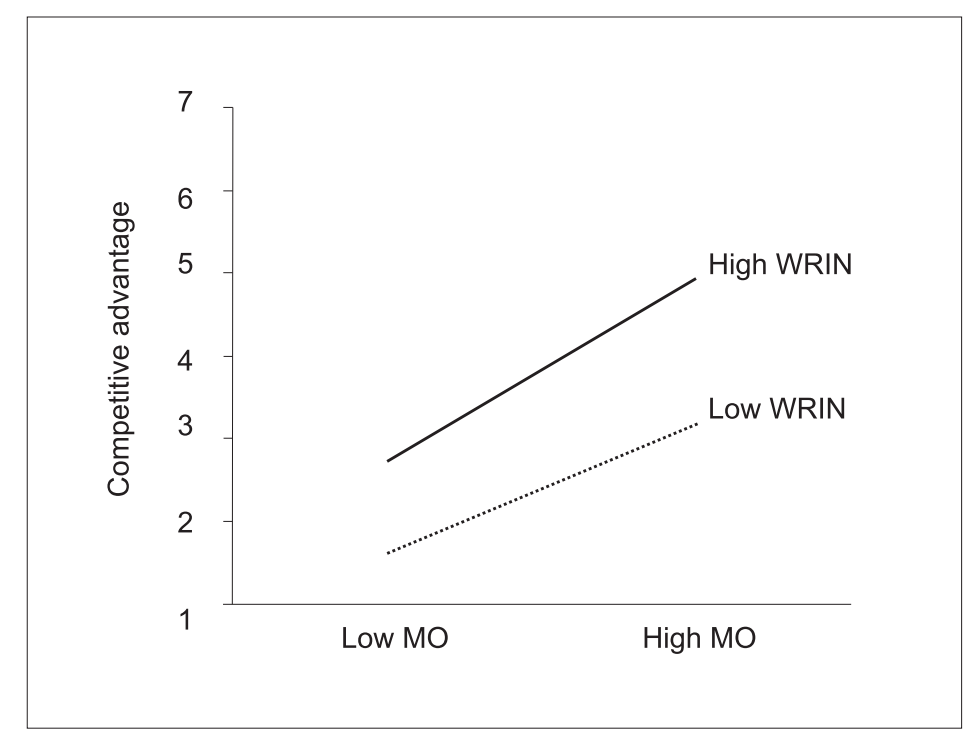

To test for the mediating effect of competitive advantage in the relationship between $\mathrm{MO}$ and business performance (H3), we followed the procedure by Baron and Kenny (1986). First, the impact of $\mathrm{MO}$ on business performance, without the mediator was examined. The direct relationship between MO 
DRUŠ. ISTRAŽ. ZAGREB GOD. 26 (2017), BR. 4, STR. 583-604

TALAJA, A., MIOČEVIĆ D., ALFIREVIĆ, N PAVIČIĆ, J. MARKET ORIENTATION. and business performance was statistically significant $(\beta=0.49$, $p<0.01$ ), with $R^{2}$ of 0.245 . Next, we included the CA construct acting as a mediator in the proposed relationship and there was a significant decrease in the path coefficient on the relationship between $\mathrm{MO}$ and business performance $(\Delta \beta=-0.36)$, and the explained variance of the endogenous construct (business performance) rose to $0.481\left(\Delta R^{2}=0.236\right)$. The total effect of MO on business performance was 0.491 . Based on these findings we conclude that competitive advantage is a partial mediator in the relationship between $\mathrm{MO}$ and business performance, which leads to the acceptance of $\mathrm{H} 3$.

Based on the tenets of the RBV of the firm, this study has investigated the indirect effects that underlie the relationships among $\mathrm{MO}$, competitive advantage and business performance. This study offers novel insights and suggests that: 1) MO has a more significant impact on competitive advantage when the firm has highly developed VRIN resources, and 2) competitive advantage mediates the relationship between $\mathrm{MO}$ and business performance. This study has tested three hypotheses. The findings of this study contribute both to the strategic marketing and strategic management literatures.

Drawing on the research that investigated the intersection of MO and RBV, in this study we explored how market-oriented behaviors increase competitive advantage and business performance through the intervening role of VRIN resources. Previous studies have addressed the indirect effects of $\mathrm{MO}$ on a firm's competitiveness through various resources and capabilities (e.g., Ngo \& O'Cass, 2012). However, extant literature is at best partial in explaining the interplay MO has with other strategic resources and capabilities. This study is first to investigate the interplay between MO and VRIN resources that represent the most comprehensive framework in valorising a firm's strategic resources (Barney, 1986). In our study we offer arguments that MO represents a strategic competence which enhances the better utilization of market-based assets/resources. In this context, we follow Hunt and Morgan's (1995) proposition of MO as a comprehensive "organizing framework", but being applicable to development of all strategically relevant (i.e. VRIN) resources and capabilities. We argue that market-oriented behaviors need substantial support in the form of VRIN resources in order to produce competitive advantage that is sustainable in the long run. The findings from our study show that MO directly and indirectly (through VRIN resources) increases competitive advantage and that competitive advantage leads to higher levels of a firm's performance. 
DRUŠ. ISTRAŽ. ZAGREB GOD. 26 (2017), BR. 4 STR. 583-604

TALAJA, A., MIOČEVIĆ D., ALFIREVIĆ, N. PAVIČIĆ, J.: MARKET ORIENTATION.
An abundant body of strategic marketing literature has found positive and direct effects of $\mathrm{MO}$ on firm performance outcomes (Ellis, 2006; Jaworski \& Kohli, 1993; Kirca, Jayachandran, \& Bearden, 2005; Narver \& Slater, 1990), whereas strategic management literature viewed $\mathrm{MO}$ as one of the four strategic orientations (along with entrepreneurship, innovativeness and organizational learning), which build the firm's positional advantage (Hult \& Ketchen, 2001). In this paper we challenge these ideas and offer theoretical arguments along with the empirical evidence that: 1) MO is a central "organizing framework" (Hunt \& Morgan, 1995) and strategic capability (Foley \& Fahy, 2009) that increases competitive advantage and 2) the competitive advantage is a missing link that comprehensively explains the value-added impact of $\mathrm{MO}$ on business performance.

Our study offers some specific guidelines for managers. As advocated by the study's findings, MO significantly improves a firm's competitiveness and business performance. MO represents a capability that enables a firm to gather and utilize market intelligence with the goal of better connecting to its customer base. However, managing market information is a resource consuming activity suggesting that firms need to deploy a significant amount of strategic VRIN resources. In this way, market-oriented behaviors pay off in terms of leveraging the competitive advantage that enhances business performance.

Although our study contributes to MO literature with some novel ideas, several limitations and potential avenues for further research must be acknowledged. This study was based on a nationwide survey conducted among medium and large-sized firms in the Republic of Croatia. Therefore, the findings must be interpreted with caution, as they may vary with respect to other national contexts. Hence, future studies may reveal contextual differences by examining how $\mathrm{MO}$ influences specific aspects of competitive advantage and business performance in different industrial settings (e.g., manufacturing industry vs. service provider firms).

Future studies could also reveal other possible avenues for studying MO's influence on organizational outcomes by employing different methodological approaches. Nowadays, strategic marketing scholars are increasingly relying on qualitative inquiry (e.g., Cauzo Bottala \& Revilla Camacho, 2013). The in-depth interpretive approach could be fruitful for exploring and discovering new dimensions of $\mathrm{MO}$ as well as its relationship with organizational processes other than ones investigated in this study.

This study's inquiry was developed in light of certain gaps that exist in the MO literature. However, future studies 
should focus on a more robust nomological network by including other than financial metrics. An extension of the nomological network would provide clearer evidence of the consequences of MO practices on key metrics that are of great importance to contemporary strategic marketing research.

\section{APPENDIX 1}

\section{Measurement scales}

Market orientation

Intelligence generation

MO1 In our company we do a lot of in-house market research.

MO2 In our company we collect industry information by formal and informal means.

MO3 In our company, we are slow to detect changes in our customers' product references. (R)

MO4 In our company we are slow to detect fundamental shifts in our industry (eg. competition, technology, regulation). (R)

MO5 We periodically review the likely effect of changes in our business environment (e.g., regulation) on customers.

Intelligence dissemination

MO6 A lot of informal "hall talk" in this business unit concerns our competitors' tactics or strategies.

MO7 Marketing personnel in our business unit spend time discussing customers' future needs with other functional departments.

MO8 When something important happens to a customer, competitor or industry, the whole business unit knows about it within a short period.

MO9 Data on customer satisfaction are disseminated at all levels in this business unit on a regular basis.

MO10 We are quick to respond to significant changes in our competitors' pricing structures.

MO11 If a major competitor were to launch an intensive campaign targeted at our customers, we would implement a response immediately.

MO12 Principles of market segmentation drive new product development efforts in this business unit.

MO13 We periodically review our product development efforts to ensure that they are in line with what customers want. ges in our customer's product or service needs. (R) 
DRUŠ. ISTRAŽ. ZAGREB GOD. 26 (2017), BR. 4 STR. 583-604

TALAJA, A., MIOČEVIĆ, D., ALFIREVIĆ, N., PAVIČIĆ, J.: MARKET' ORIENTATION
VRIN Resources

PHY_RES Physical resources (i.e., technology, land, plant and equipment, raw materials, etc.)

HUM_RES The human resources (i.e., education, experience, relations between employees)

ORG_RES Organizational resources (i.e., relationships with other firms, distribution and selling channels)

INT_RES Intellectual resources (i.e., patents, copyrights, etc.)

FIN_RES Financial resources (i.e., capital, cash, shares, earnings, etc.)

Competitive advantage

CA1 General advantage over competitors.

CA2 Sustainability of acquired competitive advantage.

CA3 Quality and image of the products/services.

CA4 Price of the products/services.

CA5 Production costs of products/Delivery costs of services.

CA6 Customer satisfaction with products/services.

Business performance

PERF1 Sales revenues.

PERF2 Sales growth

PERF3 Profitability.

PERF4 Market share.

PERF5 Market share growth.

PERF6 Performance sustainability.

(R) - reversely coded

\section{REFERENCES}

Agić, E., Činjarević, M., Kurtović, E., \& Čičić, M. (2016). Strategic marketing patterns and performance implications. European Journal of Marketing, 50(12), 2216-2248. https://doi.org/10.1108/EJM-08-2015-0589

Amit, R., \& Shoemaker, P. (1993). Strategic assets and organizational rent. Strategic Management Journal, 14(1), 33-46. https://doi.org/10. 1002/smj.4250140105

Bagozzi, R. P., \& Yi, Y. (1988). On the evaluation of structural equation models. Journal of the Academy of Marketing Science, 16(1), 74-94. https://doi.org/10.1007/BF02723327

Barney, J. B. (1986). Strategic factor markets: Expectations, luck and business strategy. Management Science, 32(10), 1231-1241. https://doi. org/10.1287/mnsc.32.10.1231

Barney, J. B. (1991). Firm resources and sustained competitive advantage. Journal of Management, 17(1), 99-120. https://doi.org/10.1177/ 014920639101700108 
DRUŠ. ISTRAŽ. ZAGREB GOD. 26 (2017), BR. 4, STR. 583-604

TALAJA, A., MIOČEVIĆ, D., ALFIREVIĆ, N PAVIČı́́, J. MARKET ORIENTATION.
Baron, R. M., \& Kenny, D. A. (1986). The moderator-mediator variable distinction in social psychological research: Conceptual, strategic and statistical considerations. Journal of Personality and Social Psychology, 51(6), 1173-1182. https://doi.org/10.1037/0022-3514.51.6.1173

Božić, L., \& Rajh, E. (2008). Procjena psihometrijskih karakteristika ljestvice za mjerenje tržišne orijentacije [The assessment of psychometric characteristics of a scale for measuring market orientation]. Ekonomski pregled, 59(1-2), 38-50. Available at http://hrcak.srce.hr/20819 Cacciolatti, L., \& Lee, S. H. (2016). Revisiting the relationship between marketing capabilities and firm performance: The moderating role of market orientation, marketing strategy and organisational power. Journal of Business Research, 69(12), 5597-5610. https://doi.org/ 10.1016/j.jbusres.2016.03.067

Cauzo Bottala, L., \& Revilla Camacho, M. Á. (2013). A qualitative and longitudinal analysis of market orientation. The Service Industries Journal, 33(7-8), 694-704. https://doi.org/10.1080/02642069.2013.740465

Chin, W. W., Marcolin, B. L., \& Newsted, P. R. (2003) A partial least squares latent variable modeling approach for measuring interaction effects: Results from a Monte Carlo simulation study and an electronic-mail emotion/adoption study. Information Systems Research, 14(2), 189-217. https://doi.org/10.1287/isre.14.2.189.16018

Chin, W. W. (2010). How to write up and report PLS analyses. In V. Esposito Vinzi, W. Chin, J. Hensler, \& H. Wold (Eds.), Handbook of partial least squares (pp. 655-689). Heidelberg: Springer. https://doi. org/10.1007/978-3-540-32827-8_29

Collis, D. J. (1994). Research note: How valuable are organizational capabilities? Strategic Management Journal, 15(S1), 143-152. https://doi. org/10.1002/smj.4250150910

Connor, T. (2007). Market orientation and performance. Strategic Management Journal, 28(9), 957-959. https://doi.org/10.1002/smj.618

Day, G. S. (1994). The capabilities of market-driven organizations. Journal of Marketing, 58(4), 37-52. https://doi.org/10.2307/1251915

Day, W. S., \& Wensley, R. (1988). Assessing advantage: A framework for diagnosing competitive superiority. Journal of Marketing, 52(2), 1-20. https://doi.org/10.2307/1251261

Deshpande, R., Farley, J. U., \& Webster, F. (1993). Corporate culture, customer orientation, and innovativeness in Japanese firms: A quadrad analysis. Journal of Marketing, 57, 23-37. https://doi.org/10. $2307 / 1251521$

Ellis, P. D. (2006). Market orientation and performance: A metaanalysis and cross-national comparisons. Journal of Management Studies, 43(5), 1089-1107. https://doi.org/10.1111/j.1467-6486.2006.00630.x

Foley, A., \& Fahy, J. (2009). Seeing market orientation through a capabilities lens. European Journal of Marketing, 43(1-2), 13-20. https:// doi.org/10.1108/03090560910923201

Fornell C., \& Larcker, D. P. (1981) Structural equation models with unobservable variables and measurement errors. Journal of Marketing Research, 18(2), 39-50. https://doi.org/10.2307/3150980

Gaur, S. S., Vasudevan, H., \& Gaur, A. S. (2011). Market orientation and manufacturing performance of Indian SMEs: Moderating role 
DRUŠ. ISTRAŽ. ZAGREB GOD. 26 (2017), BR. 4 STR. 583-604

TALAJA, A., MIOČEVIĆ D., ALFIREVIĆ, N. PAVIČIĆ, J. MARKET ORIENTATION. of firm resources and environmental factors. European Journal of Marketing, 45(7/8), 1172-1193. https://doi.org/10.1108/03090561111137660

Grant, R. M. (1991). The resource-based theory of competitive advantage: Implications for strategy formulation. California Management Review, 33(3), 114-135. https://doi.org/10.2307/41166664

Götz, O., Liehr-Gobbers, K., \& Krafft, M. (2010). Evaluation of structural equation models using the Partial Least Squares (PLS) approach. In V. Esposito Vinzi, W. Chin, J. Hensler, \& H. Wold (Eds.), Handbook of partial least squares (pp. 691-711). Heidelberg: Springer. https://doi.org/10.1007/978-3-540-32827-8_30

Hair, J. F., Black, W. C., Babin, B. J., \& Anderson, R. E. (2010). Multivariate data analysis. New Jersey: Pearson Prentice Hall.

Hao Ma (2000). Competitive advantage and firm performance. Competitiveness Review: An International Business Journal, 10(2), 15-32. https://doi.org/10.1108/eb046396

Hult, G. T. M., Ketchen, D. J., \& Slater, S. F. (2005). Research notes and commentaries - Market orientation and performance: An integration of disparate approaches. Strategic Management Journal, 26(12), 1173-1181. https://doi.org/10.1002/smj.494

Hult, G. T. M., \& Ketchen, D. J. (2001). Research notes and commentaries - Does market orientation matter? A test of the relationship between positional advantage and performance. Strategic Management Journal, 22(9), 899-906. https://doi.org/10.1002/smj.197

Hunt, S. D., \& Morgan, R. M. (1995). The comparative advantage theory of competition. Journal of Marketing, 59(2), 1-15. https://doi.org/ $10.2307 / 1252069$

Jaworski, B. J., \& Kohli, A. K. (1993). Market orientation: Antecedents and consequences. Journal of Marketing, 57(3), 53-70. https:/doi.org/ $10.2307 / 1251854$

Ketchen, D. J., Hult, G. T. M., \& Slater, S. F. (2007). Toward greater understanding of market orientation and the resource-based view. Strategic Management Journal, 28(9), 961-964. https://doi.org/10.1002/ smj.620

Kirca, A. H., Jayachandran, S., \& Bearden, W. O. (2005). Market orientation: A meta-analytic review and assessment of its antecedents and impact on performance. Journal of Marketing, 69(2), 24-41. https:// doi.org/10.1509/jmkg.69.2.24.60761

Kohli, A. K., \& Jaworski, B. J. (1990). Market orientation: The construct, research propositions, and managerial implications. Journal of Marketing, 54(2), 1-18. https://doi.org/10.2307/1251866

Kohli, A. K., Jaworski, B. J., \& Kumar, A. (1993). MARKOR: A measure of market orientation. Journal of Marketing Research, 30(4), 467-477. https://doi.org/10.2307/3172691

Kumar, V., Jones, E., Venkatesan, R., \& Leone, R. P. (2011). Is market orientation a source of sustainable competitive advantage or simply the cost of competing? Journal of Marketing, 75(1), 16-30. https://doi .org/10.1509/jmkg.75.1.16

Lonial, S. C., \& Carter, R. E. (2015). The impact of organizational orientations on medium and small firm performance: A resource-based 
DRUŠ. ISTRAŽ. ZAGREB GOD. 26 (2017), BR. 4, STR. 583-604

TALAJA, A., MIOČEVIĆ D., ALFIREVIĆ, N PAVIČı́́, J. MARKET ORIENTATION perspective. Journal of Small Business Management, 53(1), 94-113. https:/ doi.org/10.1111/jsbm.12054

Makadok, R. (2001). Toward a synthesis of the resource-base and dynamic capability view of rent creation. Strategic Management Journal, 22(5), 387-401. https://doi.org/10.1002/smj.158

Miocevic, D., \& Crnjak-Karanovic, B. (2011). Cognitive and information-based capabilities in the internationalization of small and medium-sized enterprises: The case of Croatian exporters. Journal of Small Business Management, 49(4), 537-557. https://doi.org/10.1111/j.1540-627 X.2011.00335.X

Morgan, N. A., Slotegraaf, R. J., \& Vorhies, D. W. (2009). Linking marketing capabilities with profit growth. International Journal of Research in Marketing, 26(4), 284-293. https://doi.org/10.1016/j.ijresmar.2009.06.005

Morgan, N. A., Vorhies, D. W., \& Mason, C. H. (2009). Market orientation, marketing capabilities, and firm performance. Strategic Management Journal, 30(8), 909-920. https://doi.org/10.1002/smj.764

Murray, J. Y., Gao, G. Y., \& Kotabe, M. (2011). Market orientation and performance of export ventures: The process through marketing capabilities and competitive advantages. Journal of the Academy of Marketing Science, 39(2), 252-269. https://doi.org/10.1007/s11747-010-0195-4 Narver, J. D., \& Slater, S. F. (1990). The effect of a market orientation on business profitability. Journal of Marketing, 54(4), 20-35. https:// doi.org/10.2307/1251757

Navarro, A., Losada, F., Ruzo, E., \& Diez, J. A. (2010). Implications of perceived competitive advantages, adaptation of marketing tactics and export commitment on export performance. Journal of World Business, 45(1), 49-58. https://doi.org/10.1016/j.jwb.2009.04.004

Newbert, S. L. (2007). Empirical research on the resource-based view of the firm: An assessment and suggestions for future research. Strategic Management Journal, 28(2), 121-146. https://doi.org/10.1002/smj.573

Newbert, S. L. (2008). Value, rareness, competitive advantage, and performance: A conceptual-level empirical investigation of the resource-based view of the firm. Strategic Management Journal, 29(7), 745-768. https://doi.org/10.1002/smj.686

Ngo, L. V., \& O'Cass, A. (2012). In search of innovation and customer-related performance superiority: The role of market orientation, marketing capability, and innovation capability interactions. Journal of Product Innovation Management, 29(5), 861-877. https://doi.org/10. 1016/j.indmarman.2011.11.018

O'Cass, A., \& Sok, P. (2014). The role of intellectual resources, product innovation capability, reputational resources and marketing capability combinations in firm growth. International Small Business Journal, 32(8), 996-1018. https://doi.org/10.1177/0266242613480225

O'Cass, A., Ngo, L. V., \& Siahtiri, V. (2015). Marketing resource-capability complementarity and firm performance in B2B firms. Journal of Business E Industrial Marketing, 30(2), 194-207. https://doi.org/10.1108/ JBIM-05-2012-0087

Pecotich, A., Crnjak-Karanović, B., \& Renko, N. (2007). The effects of executive marketing orientation, organizational structure, size and age on 
DRUŠ. ISTRAŽ. ZAGREB GOD. 26 (2017), BR. 4 STR. 583-604

TALAJA, A., MIOČEVIĆ D., ALFIREVIĆ, N. PAVIČIĆ, J.: MARKET ORIENTATION performance. Proceedings of the Seventh International Conference on Enterprise in Transition, 1, pp. 413-422.

Peteraf, M. A., Barney, \& J. B. (2003). Unraveling the resource-based tangle. Managerial and Decision Economics, 24(4), 309-323. https://doi. org/10.1002/mde.1126

Podsakoff, P. M., Mckenzie, S. B., Lee, J. Y., \& Podsakoff, N. P. (2003). Common method bias in behavioral research: A critical review of the literature and recommended remedies. Journal of Applied Psychology, 88(5), 879-903. https://doi.org/10.1037/0021-9010.88.5.879

Powell, T. C. (2001). Competitive advantage: Logical and philosophical considerations. Strategic Management Journal, 22(9), 875-888. https:// doi.org/10.1002/smj.173

Protogerou, A., Caloghirou, Y., \& Lioukas, S., (2008). Dynamic capabilities and their indirect impact on firm performance. Available at http:// www2.druid.dk/conferences/viewpaper.php?id $=3718 \& c f=29$

Rakthin, S., Calantone, R. J., \& Wang, J. F. (2016). Managing market intelligence: The comparative role of absorptive capacity and market orientation. Journal of Business Research, 69(12), 5569-5577. https://doi. org/10.1016/j.jbusres.2016.03.064

Reinartz, W., Haenlein, M., \& Henseler, J. (2009). An empirical comparison of the efficacy of covariance-based and variance-based SEM. International Journal of Research in Marketing, 26(4), 332-344. https:// doi.org/10.1016/j.ijresmar.2009.08.001

Snoj, B., Milfelner, B., \& Gabrijan, V. (2007). An examination of the relationships among market orientation, innovation resources, reputational resources, and company performance in the transitional economy of Slovenia. Canadian Journal of Administrative Sciences/ Revue Canadienne des Sciences de l'Administration, 24(3), 151-164. https://doi.org/10.1002/cjas.22

Spanos, Y. E., \& Lioukas, S. (2001). An examination into the causal logic of rent generation: Contrasting Porter's competitive strategy framework and the resource-based perspective. Strategic Management Journal, 22(10), 907-934. https://doi.org/10.1002/smj.174

Srivastava, R. K., Fahey, L., \& Christensen, H. K. (2001). The resource-based view and marketing: The role of market-based assets in gaining competitive advantage. Journal of Management, 27(6), 777-802. https://doi.org/10.1177/014920630102700610

Teece, D. J., Pisano, G., \& Shuen, A. (1997). Dynamic capabilities and strategic management. Strategic Management Journal, 18(7), 509-533. https://doi.org/10.1002/(SICI)1097-0266(199708)18:7<509::AIDSMJ882>3.0.CO;2-Z

Wernerfelt, B. (1984). A resource-based view of the firm. Strategic Management Journal, 5(2), 171-180. https://doi.org/10.1002/smj.4250050207

Wetzels, M., Odekerken-Schröder, G., \& van Oppen, C. (2009). Using PLS path modeling for assessing hierarchical construct models: Guidelines and empirical illustration. MIS quarterly, 33(1), 177-195. https://doi.org/10.2307/20650284

Wold, H. (1980). Model construction and evaluation when theoretical knowledge is scarce: Theory and application of partial least 
DRUŠ. ISTRAŽ. ZAGREB GOD. 26 (2017), BR. 4, STR. 583-604

TALAJA, A., MIOČEVIĆ, D., ALFIREVIĆ, N. PAVIČIĆ, J. MARKET ORIENTATION squares. In J. Kmenta \& J. Ramsey (Eds.), Evaluation of econometric models (pp. 47-74). New York: Academic Press. https://doi.org/10.1016/ B978-0-12-416550-2.50007-8

Zhang, J., \& Zhu, M. (2016). Market orientation, product innovation and export performance: Evidence from Chinese manufacturers. Journal of Strategic Marketing, 24(5), 377-397. https://doi.org/10.1080/ 0965254X.2015.1052538

\section{Tržišna orijentacija, konkurentska prednost i poslovni rezultati: istraživanje neizravnih učinaka}

Anita TALAJA, Dario MIOČEVIĆ, Nikša ALFIREVIĆ

Ekonomski fakultet, Split

Jurica PAVIČıć

Ekonomski fakultet, Zagreb

U ovom se radu ispituju nedovoljno istraženi indirektni odnosi između tržišne orijentacije, strateških resursa i poslovnih rezultata. Prethodna istraživanja identificirala su tržišnu orijentaciju kao ključnu stratešku imovinu poduzeća koja pridonosi stvaranju konkurentske prednosti i ostvarenju poslovnog uspjeha. Međutim, današnje spoznaje u najboljem slučaju djelomično objašnjavaju međuodnos između navedenih koncepata. Cili je ovog istraživanja proširenje sadašnjih spoznaja, upozoravajući na to kako se tržišna orijentacija dopunjuje s drugim procesima strateškog upravljanja koji su važni za poslovni uspjeh. Da bi se odgovorilo na istraživačka pitanja, u radu je razvijen konceptualni model sa tri hipoteze. Primarni podatci prikupljeni su upitnikom na uzorku od 265 srednjih i velikih poduzeća iz Republike Hrvatske. Nalazi istraživanja pokazuju da tržišna orijentacija povećava konkurentsku prednost na višim razinama strateških resursa. Nalazi također sugeriraju da konkurentska prednost posreduje u odnosu između tržišne orijentacije i uspješnosti poslovanja. Na kraju rada predstavljaju se teorijske i menadžerske implikacije sa smjernicama za buduća istraživanja.

Ključne riječi: resursni pristup, tržišna orijentacija, konkurentska prednost, poslovni rezultati

\section{(c) (i) $($) $\ominus$}

Međunarodna licenca / International License:

Creative Commons Attribution-NonCommercial-NoDerivatives 4.0. 